\title{
Third Molar Emergence in a Modern Japanese Population
}

\author{
Hiroyuki YAMADA
}

Department of Anatomy, School of Dentistry, Aichi-Gakuin University

\begin{abstract}
The emergence ages of third molars in a modern Japanese population were examined, and the results were compared with those for other ethnic groups. The subjects of the study consisted of 983 individuals (539 males and 444 females) aged 18 to 40 years. The family backgrounds of all of the individuals studied were presumed to be of the middle-class socioeconomic group. In each case, a third molar was judged to have erupted if any part of the tooth crown had pierced the gingiva. The median emergence age was estimated by probit analysis of the incidence of eruption, measured as the number of persons at each age level with one or more third molars erupted.

The median emergence age was 19.59 years for males and 20.67 years for females. More third molars had erupted in males than in females at any given age. Also, mandibular molars tended to have erupted earlier than their maxillary counterparts, especially in females. Viewed from a global perspective, the Japanese population was characterized as experiencing third molar emergence at a relatively late age.
\end{abstract}

Key Words Eruption time, Third molar, Probit analysis, Modern Japanese

\section{Introduction}

Compared with other permanent teeth, the third molar displays considerable variability in tooth formation. Cusp calcification of this tooth commences at around the eighth year, and apical closure is not complete until the twentieth year of life. More than twelve years are required to complete its formation (GARN et al., 1962; GRAVELY, 1965). As a result of evidence showing a great deal of variability in tooth size and morphology, this molar is considered to be highly sensitive to environmental influences. It has also been suggested in response to clinical data that delayed emergence of the third molar has undesirable effects on convalescence from orthodontic treatment (SEINO et al., 1990).

A number of studies of the emergence of permanent teeth have been undertaken over the years, providing researchers with valuable information (OKAMOTO, 1934; CLEMENTS et al., 1953; DAHLBERG et al., 1958; EVELETH, 1966). However, the eruption of the third molar is relatively rare before the age of 18 years, and even after this age the number of third molars which pierce the gingiva tends to be low due to congenital absence or impaction. For these reasons, perhaps, few calculations of the median emergence age of this tooth in specific ethnic populations have been performed (MALCOLM and BUE, 1970; HASSANALI, 1985).

The present study aims to determine the ages 
of emergence of the third molar in a modern Japanese population, and to compare the results obtained with those of other ethnic groups.

\section{Subjects and Methods}

The subjects of this study consisted of 983 individuals (539 males and 444 females) aged 18 to 40 years, the majority of whom were students at the School of Dentistry and the School for Oral Hygienists and Dental Technicians at Aichi Gakuin University in Nagoya, Japan. All of the subjects were regarded as belonging to the middle-class socioeconomic group, based on their family backgrounds. The examination of the subjects was carried out between the months of June and September, 1991.

The emergence of third molars on both sides of the oral cavity was studied by oral inspection using a dental mirror under sufficient light. A third molar was judged to have erupted if any part of the tooth crown had pierced the gingiva. None of the subjects examined had ever had a first or second molar extracted, nor had any subject experienced extraction of a fully impacted third molar. No X-ray examinations were carried out; hence, congenitally missing or fully impacted teeth were regarded to be unerupted in the present study.

The median emergence time was estimated by probit analysis using the method described by GOLDSTEIN (1964). This analysis method is considered to be an efficient method of estimating the median emergence age of permanent teeth (DAHLBERG and MENEGAZ-BOCK, 1958; CLEMENTS et al., 1958; GATES, 1964). In this study, the percentage of persons with one or more third molars erupted at each age level was converted to a probit value, and the resulting linear distribution was subjected to regression analysis to find the median age of emergence.

\section{Results}

The percentage distributions of persons with one or more third molars erupted at each age level are listed in Tables 1 and 2, and plotted as a histogram in Fig. 1. The incidence of emergence for both males and females rose steeply up to 22 years, leveling off thereafter. Around $80 \%$ of the persons studied had one or more third molars erupted after the age of 22 years.

Males had a greater incidence of eruption at every age level. The mandibular third molars tended to have erupted earlier than their maxillary counterparts for females; however, no such

Table 1. Percentage distribution of individuals with one or more third molars erupted at each age level in Japanese males

\begin{tabular}{lccccc}
\hline Age & $\begin{array}{c}\text { Number of } \\
\text { individuals } \\
\text { examined }\end{array}$ & $\begin{array}{c}\text { Maxilla } \\
\%\end{array}$ & $\begin{array}{c}\text { Mandible } \\
\%\end{array}$ & $\begin{array}{c}\text { Max. \& Man. } \\
\%\end{array}$ & $\begin{array}{c}\text { With all third } \\
\text { molars erupted } \\
\%\end{array}$ \\
\hline 18 & 64 & $10.9(7)$ & $21.9(14)$ & $25.0(16)$ & $6.3(4)$ \\
19 & 66 & $40.9(27)$ & $34.9(23)$ & $50.0(33)$ & $19.7(13)$ \\
20 & 72 & $50.0(36)$ & $61.1(44)$ & $65.3(47)$ & $20.8(15)$ \\
21 & 73 & $63.0(46)$ & $57.5(42)$ & $69.9(51)$ & $27.4(20)$ \\
22 & 72 & $68.1(49)$ & $69.4(50)$ & $80.6(58)$ & $30.6(22)$ \\
23 & 65 & $70.8(46)$ & $58.5(38)$ & $83.1(54)$ & $24.6(16)$ \\
24 & 34 & $73.5(25)$ & $61.8(21)$ & $79.4(27)$ & $35.3(12)$ \\
$25-40$ & 93 & $68.8(64)$ & $64.5(60)$ & $77.4(72)$ & $47.3(44)$ \\
\hline
\end{tabular}

( ): Number of individuals with one or more third molars erupted. 
Table 2. Percentage distribution of individuals with one or more third molars erupted at each age level in Japanese females

\begin{tabular}{lccccc}
\hline Age & $\begin{array}{c}\text { Number of } \\
\text { individuals } \\
\text { examined }\end{array}$ & $\begin{array}{c}\text { Maxilla } \\
\%\end{array}$ & $\begin{array}{c}\text { Mandible } \\
\%\end{array}$ & $\begin{array}{c}\text { Max. \& Man. } \\
\%\end{array}$ & $\begin{array}{c}\text { With all third } \\
\text { molars erupted } \\
\%\end{array}$ \\
\hline 18 & 104 & $12.5(13)$ & $16.4(17)$ & $21.2(22)$ & $4.7(5)$ \\
19 & 83 & $13.3(11)$ & $26.5(22)$ & $28.9(24)$ & $8.4(7)$ \\
20 & 47 & $42.6(20)$ & $51.1(24)$ & $53.2(25)$ & $27.7(13)$ \\
21 & 55 & $45.5(25)$ & $41.8(23)$ & $60.0(33)$ & $21.8(12)$ \\
22 & 31 & $54.8(17)$ & $67.7(21)$ & $77.4(24)$ & $35.5(11)$ \\
23 & 37 & $59.5(22)$ & $62.2(23)$ & $78.4(29)$ & $27.0(10)$ \\
24 & 17 & $52.9(9)$ & $58.8(10)$ & $70.6(12)$ & $29.4(5)$ \\
$25-40$ & 70 & $67.1(47)$ & $61.4(43)$ & $78.6(55)$ & $40.0(28)$ \\
\hline
\end{tabular}

( ): Number of individuals with one or more third molars erupted.

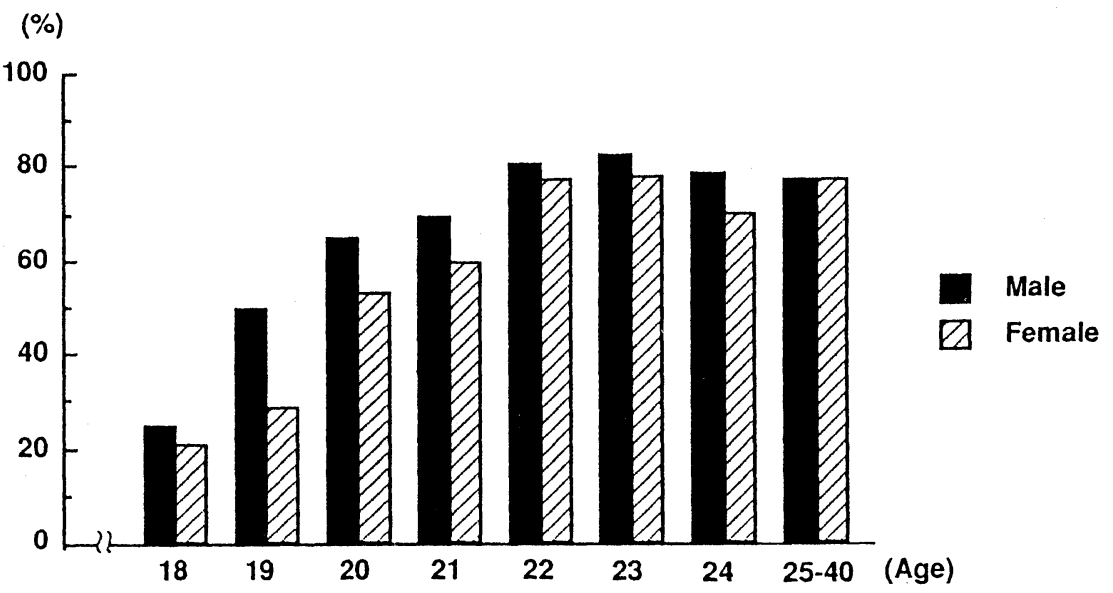

Fig. 1. Percentage of Japanese males and females with one or more third molars erupted at a given age.

tendency to a definite eruption order was evident among the male subjects. The percentage of persons with all four third molars erupted ranged from $21 \%$ to $35 \%$ for males, and from $22 \%$ to $36 \%$ for females, during the ages of 20 to 24 years.

The percentages of emerged third molars are listed in Table 3. The figures showing potential eruptions in this table are calculated at the maximum of two per dental arch. No distinction is made between right- and left-side molars in this table, since no statistically significant difference is expected between the emergence of the right and left third molars (FANNING, 1962). The incidence of third molar eruption expressed as the percentage of teeth erupted was somewhat lower (approximately $10 \%$ lower during the ages of 20 to 24 years for both the maxilla and the mandible), but similar in pattern to that found when expressed as the number of persons with erupted teeth.

Table 4 shows the average number of erupted 
Table 3. Percentage distribution of third molar teeth erupted at each age level in a Japanese population

\begin{tabular}{|c|c|c|c|c|c|c|}
\hline \multirow[b]{2}{*}{ Age } & \multicolumn{3}{|c|}{ Males } & \multicolumn{3}{|c|}{ Females } \\
\hline & $\begin{array}{c}\text { No. of potential } \\
\text { eruptions }\end{array}$ & $\begin{array}{c}\text { Maxilla } \\
\%\end{array}$ & $\begin{array}{c}\text { Mandible } \\
\%\end{array}$ & $\begin{array}{l}\text { No. of potential } \\
\text { eruptions }\end{array}$ & $\begin{array}{c}\text { Maxilla } \\
\%\end{array}$ & $\begin{array}{c}\text { Mandible } \\
\% 0\end{array}$ \\
\hline 18 & 128 & 10.2 & $15.6 \quad(20)$ & 208 & $11.1(23)$ & $12.5(26)$ \\
\hline 19 & 132 & $35.6 \quad(47)$ & $31.1 \quad(41)$ & 166 & 11.5 (19) & $21.7(36)$ \\
\hline 20 & 144 & $41.7 \quad(60)$ & $48.6 \quad(70)$ & 94 & 35.1 (33) & 45.7 (43) \\
\hline 21 & 146 & $55.5 \quad(81)$ & 47.3 (69) & 110 & 39.1 (43) & $35.5(39)$ \\
\hline 22 & 144 & $56.3 \quad(81)$ & $57.6 \quad(83)$ & 62 & $48.4(30)$ & $59.7(37)$ \\
\hline 23 & 130 & $57.7 \quad(75)$ & $49.2 \quad(64)$ & 74 & $48.7(36)$ & $55.4(41)$ \\
\hline 24 & 68 & $63.2 \quad(43)$ & 54.4 & 34 & 44.1 (15) & 47.1 (16) \\
\hline $25-40$ & 186 & 63.4 (118) & 59.7 (111) & 140 & $58.6(82)$ & $56.4(79)$ \\
\hline
\end{tabular}

( ): Number of teeth erupted.

Table 4. Number of permanent third molars erupted at each age level

\begin{tabular}{ccc}
\hline Age & Males & Females \\
\hline 18 & 0.52 & 0.47 \\
19 & 1.33 & 0.66 \\
20 & 1.81 & 1.62 \\
21 & 2.05 & 1.49 \\
22 & 2.28 & 2.16 \\
23 & 2.14 & 2.08 \\
24 & 2.35 & 1.82 \\
$25-40$ & 2.46 & 2.27 \\
\hline
\end{tabular}

third molars per person at each age level. The number of erupted third molars appears in this chart to have increased gradually with age; at the age of 22 years, the averages were 2.28 teeth for males and 2.16 teeth for females.

Table 5 shows the median age of subjects with one or more erupted third molars. The median ages were 19.6 years for males and 20.7 years for females. The mandibular third molars of males emerged 0.3 years earlier than did the maxillary teeth, which erupted at 20.4 years. The same trend was observed for females, but the magnitude of the difference of third molar eruption in maxillary and mandibular dentitions was much greater, at 1.1 years.

\section{Discussion}

The median emergence age of permanent teeth has, in general, been estimated by probit analysis, or by KARBER's method, on the basis of the incidence of tooth emergence at specific ages (CLEMENTS et al., 1953; GARN et al., 1962; LEE and CHANG, 1965; MALCOLM and BUE, 1970). This approach, which I will for convenience term the "total emergence" approach, is used in the study of third molar emergence by researchers such as HASSANALI (1985). Others, such as FANNING (1962), base their estimates on the

Table 5. Median emergence time of third molars

\begin{tabular}{|c|c|c|c|c|c|c|}
\hline & \multicolumn{2}{|c|}{ Maxilla } & \multicolumn{2}{|c|}{ Mandible } & \multicolumn{2}{|c|}{ Max. and Man. } \\
\hline & Median & S E & Median & S E & Median & $\mathrm{S} \mathrm{E}$ \\
\hline Males & 20.38 & 0.21 & 20.12 & 0.22 & 19.59 & 0.12 \\
\hline Females & 22.00 & 0.38 & 20.88 & 0.23 & 20.67 & 0.15 \\
\hline Sex difference & 1.62 & & 0.76 & & 1.08 & \\
\hline
\end{tabular}


percentage of subjects with one or more erupted third molars at each age group, a method which may by contrast be called a "minimum emergence" approach.

In some cases, there may be good reason for adopting this latter approach, as not all third molars necessarily erupt, due to congenital absence and impaction, in certain ethnic groups. In the present study, for example, the incidence of eruption of third molars was found to be only around $60 \%$ in the maxilla and mandible for both sexes, even in subjects aged 25 to 40 years (Table 2). Further, the percentage of third molars erupted at each age level between 20 to 24 years was approximately $10 \%$ lower for each jaw than that of persons who had one or more third molars. For the purpose of this study, therefore, I have adopted the minimum emergence approach, as it is expected to yield somewhat higher reliability.

\section{Variation among ethnic groups}

The median age of emergence for Japanese male subjects was 20.4 years for maxillary, and 20.1 years for mandibular third molars. Similar emergence ages have been reported for American males living in Boston, where the median ages, found using the minimum emergence approach, were 20.5 years for the maxilla and 19.8 years for the mandible (FANNING, 1962).

Median ages of emergence have been calculated for other ethnic populations, using the total emergence approach. This approach is appropriate to populations showing the characteristics of earlier eruption times and higher eruption frequency for the third molars. It is important to bear in mind when comparing the results of these studies, however, that the median emergence ages estimated using this approach will tend to be somewhat later than those calculated using the minimum emergence approach.

A comparative study of the median third molar emergence age of males born in Kenya has revealed that the age is 18.8 to 18.9 years for the maxilla, and 18.0 to 18.2 years for the mandible, in native Kenyans. The median ages for Asians born in Kenya, by comparison, were 20.7 years for the maxilla and 19.9 to 20.0 years for the mandible (HASSANALI, 1985).

Much earlier third molar eruption ages have been reported in Oceania. Median ages of 18.4 years for the maxilla and 17.0 years for the mandible have been found for the Cook Islanders in Polynesia (YAMADA et al., 1992). In Australian Aboriginals, the average ages of emergence were found to be 16.8 years for the maxilla and 16.5 years for the mandible (BROWN, 1978). Moreover, children in the town of Lae, located in the lowlands of New Guinea, show average emergence ages of 16.4 years for the maxilla and 14.8 years for the mandible (MALCOLM and BUE, 1970).

On the other hand, the percentage of persons with all four third molars erupted was $27.4 \%$ for males at the age of 21 years in the present study. Similar distributions have been described for the Japanese male populations reported on previously, the range being from $25 \%$ to $38 \%$ for the same age groups (OHGOSHI and KUROSAWA, 1958; KIKUCHI, 1970; MARUYAMA, 1983). Asians born in Kenya showed a considerably high tendency to get all of their third molars, the rate being about $60 \%$ at 22 years of age (HASSANALI, 1985), whereas Bostonian boys older than 20 years of age show a low rate of only $24 \%$ (FANNING, 1962).

In Africa, however, $75 \%$ of East Africans and approximately $70 \%$ of Kenyans have all their third molars at the age of 21 years (CHAGULA, 1960; HASSANALI, 1985). In a small sample of Nigerians, all third molars had already erupted by the age of 19 years (ODUSANYA and ABAYOMI, 1991).

FANNING (1962), comparing the third molar 
emergence of East Africans with his findings for Bostonians, states that such marked differences may be partly explained by a lower rate of agenesis and by less impaction of third molars in the African subjects. YAMADA et al. (1992), in examining the literature describing the mean or median ages of emergence of the other permanent teeth in populations around the globe, have found that there are two distinct population types. Africans, Polynesians, and the people of New Guinea belong to one type characterized by early eruption of permanent teeth, whereas Asians and Europeans belong to another type with later eruption ages. The authors of this report emphasized that the tropical climate is likely to be associated with early dental maturation.

Judging from the eruption times cited above, it appears that the Japanese population is characterized as a group which experiences eruption of the third molar at a relatively late age among various populations world wide.

\section{Sex differences}

Generally speaking, all permanent teeth other than the third molars characteristically tend toward earlier formation and eruption in females (CLEMENTS et al., 1953; GARN et al., 1962; LEE and CHANG, 1965; MALCOLM and BUE, 1970). The third molars, however, were found to emerge earlier in males than in females in the present study, and the same tendency holds true for other Japanese populations (OHGOSHI and KuROSAWA, 1958; MARUYAMA, 1983).

Among Asians born in Kenya, the median eruption age of the third molars was found to be earlier for males than for females by approximately 0.3 years. The eruption ages of the maxillary third molar were found to be similar for Bostonian males and females; however, the mandibular third molars erupt 0.6 years earlier for males than for females. According to GARN et al. (1962), who examined the formation and development of the mandibular third molar in Ohio children, there was no significant sex difference throughout the developmental course of the teeth.

In the Kenyan population studied by HASSANALI (1985), females exceeded males in the incidence of third molar eruption at each age from 13 to 17 years, whereas after 18 years of age, males were ahead of females in incidence. The median eruption ages were found to be lower for females by $0.3-0.4$ years. Similar tendencies have been found in the eruption ages of third molars in Nigerians and Australian Aboriginals (ODUSANYA and ABAYOMI, 1991; BROWN, 1978).

LEVESQUE et al. (1981), who studied the development of the mandibular third molar in Canadians of French descent, described that the formation of the tooth crown and root was earlier in females in all the permanent teeth but the third molar, for which the root forms earlier in males, and also that the median emergence age of this tooth was 0.5 years earlier for males.

Viewed from the ethnic perspective, populations predisposed to early emergence of other permanent teeth also are predisposed to early emergence of the third molars. Females outstrip males in third molar emergence in such populations. In populations with later eruption ages, on the other hand, females seem to tend to retarded third molar eruption. The reason for this is unknown at present.

\section{Conclusions}

This study's observations on third molar emergence time in a modern Japanese population can be summarized as follows: $50 \%$ of all persons in the population have one or more third molars erupted at the ages of 19.59 years for males and 20.67 years for females. The third molar erupts earlier in males than in females at any given age 
level. Mandibular molars tend to erupt earlier than maxillary teeth for females, but there is no definite tendency for males. The Japanese population can be characterized as a group with a relatively late third molar emergence age when viewed from a global perspective.

\section{Acknowledgements}

The author is deeply grateful to the students, faculty, and staff of Aichi-Gakuin University who participated in the study, for their cooperation in making this study a success; and to Mrs. Kaoru MANI, for typing the report.

$$
\text { 抄録 }
$$

現代日本人の第 3 大臼歯の萌出時期

山田博之

愛知学院大学歯学部学生, 歯科技工士, 歯科衛生士 ならびに大学の教職員983名（男性539名, 女性444名： 18歳から40歳）について, 第 3 大臼歯の萌出時期を調 查した. 萌出は柬冠の一部が少しでも歯肉上に露出し ていれば萌出歯とみなした。なお第 1 および第 2 大曰 歯がう蝕等で欠損している個体がある場合，この個体 は調查の対象から除外した。調査されたデー夕は男女 別々に，また各年齢毎に集計され，萌出率の算出を行つ た. 平均萌出年齢は第 3 大臼歯が 1 歯以上萌出してい る頻度からプロビット分析により推定した．えられた 結果を他の人種集団の萌出デー夕と比較した.

男性および女性とも第 3 大臼歯の萌出率は 22 才頃ま で増加していた。しかし22歳以降では男女とも萌出率 にあまり変化は認められなかった. 22 歳時における 1 歯以上萌出率は男性が $80.6 \%$ ，女性は $77.4 \%$ であった。 また平均萌出推定年齢は男性が 19.59 歳，女性は 20.67 歳であった。一般に第 3 大臼歯以外の歯では女性の方 が萌出は早いが, 第 3 大臼蒾では男性の方が早く萌出 していた（上顎では1.6歳, 下顩では 0.8 歳, 全体では 1.1歳の性差)。また下顎の方が上顎よりも早く萌出し ていた（女性）。現代日本人の第 3 大臼歯の萌出時期 を他の人種集団と比較してみると, 第 3 大臼歯以外の 歯の萌出時期と同じ傾向が認められた．すなわち，現 代日本人は他のアジアの集団や白人の集団と同様に萌 出時期が比較的遅いグループに含まれていた．

\section{References}

BROWN, T., 1978: Tooth emergence in Australian Aboriginals. Annals Hum. Biol., 5: 41-54.

CHAGULA, W.K., 1960: The age at eruption of third permanent molars in male East Africans. Am. J. Phys. Anthropol., 18: 77-82.

Clements, E.M.B., E. DAVIES-THOMAS, and K.G. PICKETT, 1953: Time of eruption of permanent teeth in British children in 1947-1948. British Medical J., 1: $1421-1424$.

DAHLBERG, A.A. and R.M. MENEGAZ-BOCK, 1958: Emergence of the permanent teeth in Pima Indian children. J. Dent. Res., 37: 1123-1140.

EVELETH, P., 1966: Eruption of permanent dentition and menarche of American children living in the tropics. Hum. Biol., 38: 60-70.

FANNING, E.A., 1962: Third molar emergence in Bostonians. Am. J. Phys. Anthropol., 20: 339-345.

GARN, S.M., A.B. LEWIS and B. BONNE, 1962: Third molar formation and its development course. Angle Orthodont., 32: 270-279.

GATES, R.E., 1964: Eruption of permanent teeth of New South Wales school children. Part I. Ages of eruption. Aust. Dent. J., 9: 211-218.

GOLDSTEIN, A., 1964: Biostatistics: An Introductory Text. Macmillan Publishing Co., Inc., New York, pp. 272.

GRAVELY, J.F., 1965: A radiographic survey of third molar development. Brit. Dent. J., 119: 397-401.

HASSANALI, J., 1985: The third permanent molar eruption in Kenyan Africans and Asians. Annal Hum. Biol., 12: 517-523.

KIKUCHI, S., 1970: Studies on the third molar teeth of men in Self-Defense Forces. Nat. Dif. Med. J., 17: 73-95. (In Japanese with English summary)

LEE, M.M.C. and K.S.F. CHANG, 1965: Eruption of the permanent dentition of southern Chinese children in Hong Kong. Archs. Oral Biol., 10: 849-861.

MALCOLM, L.A. and B. BUE, 1970: Eruption times of permanent teeth and the determination of age in New Guinean children. Trop. Geogr. Med., 22: 307-312.

MARUYAMA, Y., 1983:A study on retention of wisdom teeth in Nagasakians. Kyusyu Dent. J., 37: 841-876. (In Japanese with English summary)

ODUSANYA, S.A. and I.O. ABAYOMI, 1991: Third molar eruption among rural Nigerians. Oral Surg. Oral Med. Oral Pathol., 71: 151-154.

OHGOSHI, M. and T. KUROSAWA, 1958: A study of third molar, 1) Eruption pattern. Dent. Anat. Res. Tokyo Dent. Coll., 8: 1-6. (In Japanese)

[大越正則・黒沢俊夫, 1958 : 第 3 大臼歯に関する研 
究 その 1) 萌出型. 東京歯科大学解剖学教室業績 集, $8: 1-6]$

OKAMOTO, K., 1934: Variative statistical study on the dates of eruption of permanent teeth. Shikagakuhou, 39: 139-170. (In Japanese)

[岡本清櫻, 1934 : 永久歯萌出時期の変異統計学的研 究. 歯科学報, $39: 139-170]$

SEINO, Y., Y. KONNO, M. YAGI, T. KAMEGAI, and F. ISHIKAWA, 1990: Study of formation of mandibular third molar in malocclusion cases. J. Jpn. Orthod. Soc., 49: 623. (In Japanese)

[清野幸男 - 今野吉晃 -八木 實・亀谷哲也・石川富 士郎, 1990 : 不正咬合者の下顎第三大臼歯の発育様 態に関する研究.日矯歯誌, $49: 623]$

YAMADA, H., K. KAWAMOTO, T. TAIREA and T.V. RERE, 1992: Early emergence time of permanent teeth in children of the Cook Islands. Man and Culture in Oceania, 8: 1-18.

山田 博 之 愛知学院大学歯学部解剖学第一講座

干464 名古屋市千種区楠元町 1-100

Hiroyuki YAMADA Department of Anatomy, School of Dentistry, Aichi-Gakuin University

1-100 Kusumoto-Cho, Chikusa-Ku, Nagoya 464, Japan 